DOI 10.37882/2500-3682.2020.11.04

\title{
ПРОБЛЕМА РАЗВИТИЯ ПРОФЕССИОНАЛЬНО-ЛИЧНОСТНЫХ ХАРАКТЕРИСТИК ЧЕЛОВЕКА В КОНТЕКСТЕ СОВРЕМЕННЫХ ПСИХОЛОГО-АКМЕОЛОГИЧЕСКИХ КОНЦЕПЦИЙ
}

\section{THE PROBLEM OF THE DEVELOPMENT OF PROFESSIONAL AND PERSONAL CHARACTERISTICS OF A PERSON IN THE CONTEXT OF MODERN PSYCHOLOGICAL AND ACMEOLOGICAL CONCEPTS}

\section{Volochkov}

Summary: The article is devoted to the problem of the development of professional and personal characteristics of a person in the context of modern psychological and acmeological concepts. The theoretical approaches to the professional and wild development of a person are revealed. It is shown that the acmeological approach is based on the systemic and subjective approaches that allow to reveal the psychological and acmeological patterns and determinants of the development of professionalism. Personal and professional development of a person is revealed by acmeology as a progressive process of achieving a high level of professionalism in all types of activities. Acmeological invariants of professionalism are determined by the subjective qualities of a professional's personality. The essence of the subjectivity of a professional is defined as a special professional and personal quality associated with actively transforming properties and abilities for creative self-development and transformation of professional activity and life in general.

Keywords: professional and personal characteristics, professional and personal development, professionalism, acmeological invariants of professionalism, subjectivity.

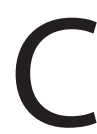

овременные условия глобализации и информатизации общественно-экономической жизни оказывают огромное влияние на сферу профессиональной жизни человека, на специфику его профессионально-личностного развития. Это связано с расширением и изменением рынка профессий, с появлением новых профессий, с необходимостью к адаптации к изменяющимся социально-экономическим условиям не только в рамках одной профессии, но в условиях обучения и получения новых профессиональных навыков на протяжении всей жизни в целях личного и профессионального развития и самореализации. Профессиональноличностное развитие современного человека требует «готовность к личностному росту и совершенствованию профессионально-важных качеств; постоянного измене-
Волочков Илья Владимирович Независимый исследователь, Президент, Международная академия траблхакинга (IAT), Пермь iv@troublehacking.com

Аннотация: Статья посвящена проблеме развития профессиональноличностных характеристик человека в контексте современных психолого-акмеологических концепций. Раскрыты теоретические подходы к профессионально-личностному развитию человека. Показано, что в основе акмеологического подхода лежат системный и субъектный подходы, позволяющие раскрыть психолого-акмеологические закономерности и детерминанты развития профессионализма. Личностно-профессиональное развитие человека раскрывается акмеологией как прогрессивный процесс достижения высокого уровня профессионализма во всех видах деятельности. Акмеологические инварианты профессионализма определяются субъектностными качествами личности профессионала. Сущность субъектности профессионала определяется как особое профессионально-личностное качество, связанное с активно преобразующими свойствами и способностями к творческому саморазвитию и преобразованию профессиональной деятельности и жизнедеятельности в целом.

Ключевые слова: профессионально-личностные характеристики, профессионально-личностное развитие, профессионализм, акмеологические инварианты профессионализма, субъектность.

ния и развития через освоение новых знаний; приобретение новых умений, навыков, компетенций» [3, с. 18]. В связи с этим актуальной становится проблема развития профессионально-личностных характеристик человека в контексте современных психолого-акмеологических концепций.

В отечественной и зарубежной науке накоплен огромный опыт научно-практических исследований, посвященных профессионально-личностному развитию человека, как в рамках одной профессии, так и в рамках изменения профессионального пути в условиях приобретения нескольких профессий. Первоначально профессионально-личностные характеристики человека как субъекта профессионального труда исследовались 
для решения задач определения профессиональной пригодности в различных областях профессиональной деятельности. Данным проблемам профессиональноличностных характеристик человека посвящены труды зарубежных ученых Ф. Гизе, У. Джеймса, Дж. Кокса, О. Липмана, Ч. Мейерса, Г. Мюнстерберга, Ч. Спирмена и др. В отечественной науке вопросы профессионально-личностных характеристик человека в аспекте их соответствия требованиям профессии интенсивно изучались в двадцатые годы XX века (М.Я. Басов, В.М. Коган, В.Н. Мясищев, И.Н.Шпильрейн и др.), а в дальнейшем в 6070 г.г. XX века советскими исследователями К.М. Гуревич, В.П. Зинченко, Е.А. Климовым, А.А. Крыловым, Н.Д. Левитовым, Б.Ф. Ломовым, К.К. Платоновым, Д.А. Ошаниным и др.

Современные концепции профессионально-личностного развития человека отличаются многообразием подходов, позволяющих описать данный процесс как системное, динамическое образование, разверчивающееся на всем жизненном пути человека. Генетический подход раскрывает профессионально-личностное развитие человека посредством исследования закономерностей его онтогенетического развития на разных этапах жизненного пути (К.А. Абульханова, Б.Г. Ананьев, В.Г. Асеев, А.А. Деркач, Б.Ф. Ломов, С.Л. Рубинштейн и др.). Социальный подход рассматривает развитие профессионально-личностных характеристик человека в процессе его социализации и индиализации (Э.Ф. Зеер, Е.А. Климов, Ю.П. Поваренков и др.). Онтологический подход к профессионально-личностному развитию человека акцентирует внимание на аксиологической составляющей профессиональной деятельности, на процессах присвоения профессиональных норм, ценностей и смыслов профессионального труда (Л.И. Анциферова, Э.Ф. Зеер, Е.А. Климов, Н.С. Пряжников и др.). Данные теоретические подходы позволили раскрыть профессионально-личностное развитие человека, особенности его профессионального самосознания и самоопределения, формирования профессиональной направленности, профессиональных мотивов, способностей и интересов, развития профессиоᄀнальных умений и навыков на разных этапах профессионализации и жизненного пути. Развитие профессионально-личностных качеств человека с этих позиций характеризуются стадиальностью, наличием кризисов при переходе от одной стадии профессионального развития человека к другой, связанных с качественной перестройкой профессионально-важных качеств личности и взаимоотношений в профессиональной сфере.

Проблемы исследования личностных качеств и характеристик человека, лежащих в основе процессов самосовершенствования, стремления к высоким достижениям в профессиональной деятельности, позволяющих достичь вершины профессионализма в профессии, наиболее полно раскрываются с позиции акмеологического подхода. Акмеологический подход отражает, прежде всего, теоретические воззрения о единстве личностно-профессионального развития человека, которое является ключевой акмеологической категорией. В основе акмеологического подхода лежат системный и субъектный подходы, позволяющие раскрыть психолого-акмеологические закономерности и детерминанты развития профессионализма, процессы саморазвития и самореализации, как в профессиональной сфере, так и в жизнедеятельности человека [3; 5; 6]. Личностно-профессиональное развитие с позиции акмеологии понимается как прогрессивный процесс, который «характеризуется совершенствованием мотивационной сферы, развитием самосознания и рефлексии, способностью проявлять творчество в работе, применять конструктивные стратегии преодоления профессиональных затруднений, готовностью к профессиональной деятельности в новых условиях, ориентацией на высокие достижения» [3, с. 17-18].

В локусе внимания исследователей с позиции акмеологии, прежде всего, находятся те профессиональноличностные характеристики человека, которые обеспечивают высокопродуктивную профессиональную деятельность и готовность к поступательному саморазвитию и самореализации, образующие, так называемые, акмеологические инварианты профессионализма. С позиции психолого-акмеологического подхода субъект личностно-профессионального развития, «это человек, двигающийся по пути профессионализации, сознательно организующий данный процесс, ставящий и реализующий цели, сознательно обогащающий опыт своей деятельности и общения, т.е. развивающийся прогрессивно» [3, с. 24]. Ключевой характеристикой субъекта личностно-профессионального развития с позиции психолого-акмеологического подхода является профессионализм. Профессионализм понимается как совокупность функционально-психологических и психофизиологических личностных характеристик человека. Рассматривая профессионализм как качественную характеристику деятельности на примере труда госслужащих, А.А. Деркач выделяет такие ее наиболее значимые показатели, как «результативность деятельности; эффективность деятельности; высокую степень ее организации и самоорганизации; информационно-технологическую культуру деятельности» [6, с. 6-7].

Исследуя акмеологические инварианты профессионализма, ученые выделяют ряд профессионально-личностных характеристик человека как субъекта профессиональной деятельности. Важным в акмеологическом понимании качеств субъекта профессиональной деятельности является удовлетворенность трудом, которая, согласно Е.Ю. Пряжниковой, Н.С. Пряжникову, становится условием принятия этой профессии как основного 
дела своей жизни и как следствие влияет на принятия человеком своей жизнедеятельности и самого себя [5]. С.В. Славнов выделяет следующие качества профессионала: коммуникабельность, контроль эмоций, сформированная адекватная Я-концепция, хорошая эрудиция, стремление к профессиональному развитию [7]. Т.Н. Щербакова, Д.Н. Мисиров выделяют такие профессионально-личностные качества человека, как «высокий самоконтроль, самоактуализация психологических, социальных образовательных и биографических возможностей, способствующих результативному включению в систему социальных и профессиональных отношений» [10, с. 50]. А.А. Деркач заявляет, что профессионализм человека обеспечивается «психологической готовностью к профессиональной деятельности; положительной мотивацией к деятельности; сформированностью профессионально важных качеств; сознанием и чувством ответственности за себя, за дело, за других; рефлексивной культурой (культурой самоотношения: знанием себя, эмоциональным отношением (к себе, самооценкой); способностью к изменениям» [6, с. 6-7].

Не менее важными для профессионала являются творческие способности и инновационный потенциал личности, который, согласно С.Г. Григорьевой связывают со следующими основными качествами:

- «творческая способность генерировать и продуцировать новые представления и идеи, а главное - проектировать и моделировать их в практических формах;

- открытость личности новому, отличному от своих представлений, что базируется на толерантности личности, гибкости и панорамности мышления;

- культурно-эстетическая развитость и образованность;

- готовность совершенствовать свою деятельность, наличие внутренних, обеспечивающих эту готовность средств и методов;

- развитое инновационное сознание, включающее ценность инновационной деятельности в сравнении с традиционной» [4, с. 10-11].

Инновационный потенциал основывается на творческом потенциале профессионала, на его творческих способностях и способности к саморазвитию. В этом случае уместно говорить о творчески саморазвивающейся личности человека. Личность, способная к творческому саморазвитию, согласно В.И. Андрееву, ориентирована «на творчество в одном или нескольких видах деятельности на основе самоактуализации все более сложных творческих задач и проблем, в процессе разрешения которых происходит самосозидание, то есть творческое позитивное изменение самопроцессов и самоспособностей» [2, c. 207].

Вышеперечисленные профессионально-личностные качества, обеспечивающие творческое саморазвитие профессионала, связаны с субъектными качествами личности. Профессионализм выступает как одна из форм проявления субъектности человека, преломляется через его субъектные профессионально-личностные характеристики. В связи с этим необходимо раскрыть теоретические взгляды к пониманию сущности и структуры субъектности.

Ученые раскрывают понятие субъектности как характеристику личности, которая связана с творческим преобразованием профессиональной деятельности и жизнедеятельности в целом. Понятие субъектность определяется как особое личностное качество, связанное с активно преобразующими свойствами и способностями. К.А. Абульхановой-Славской отмечается, что категория субъекта имеет процессуальный характер, который определяется процессами самоопределения, самосознания, саморегуляции, субъектификации, происходящими внутри личности и отражающие процессы индивидуализации на разных этапах профессиональноличностного развития человека [1]. А.М. Трещев определяет субъектную активность как особое качество личностной позиции, которая характеризует ценностно-деятельное отношение личности, включающее смыслотворчество как способность оценивать смысл и ценностную значимость профессии; готовность к действию как способность не только сделать выбор, но и нести за него ответственность; автономность как способность принять самостоятельные решения; поиск ценностных смыслов профессии, выбор варианта решения профессиональных задач, которые определяются степенью развитости рефлексивных процессов [8].

Ведущую роль в развитии субъектных качеств профессионала играют рефлексивные процессы, свойства и состояния, которые обеспечивают профессионально-личностную саморегуляцию человека как субъекта профессиональной деятельности. Рефлексия, по мнению А.И. Троянской, «выступает как механизм взаимодействия личности с профессиональным миром при посредстве рефлексивных процессов субъективации профессиональных значений и объективации профессиональных смыслов» [9, с. 82].

Другими, не менее важным личностно-профессиональными проявлениями субъектности личности, являются саморегуляционные качества человека. К.А. Абульханова-Славская описывает уровни развития саморегуляции в профессиональной деятельности человека. Если на начальных этапах профессионализации личность согласовывает свои особенности с нормами профессиональной деятельности, на втором - совершенствует качество деятельности путем оптимизации своих возможностей, то на уровне профессионализма личность обладает оптимальной стратегией и тактикой, 
проявляя творческий характер профессиональной активности и выходя за пределы деятельности, реализуя авторскую позицию в профессии [1].

Таким образом, в контексте современных психологоакмеологических концепций развитие профессиональ- но-личностных характеристик человека подразумевает развитие личности, способной к творческому саморазвитию, обладающей развитыми субъектными качествами, обеспечивающими творческий, преобразующий характер профессиональной деятельности и достижение высокого уровня профессионализма.

\section{ЛИТЕРАТУРА}

1. Абульханова-Славская К.А. Психология и сознание личности: Избранные психологические труды. - М.: РГБ, 2004. - 216 с.

2. Андреев В.И. Концепция, законы и идеология гарантированного качества образования на основе творческого саморазвития человека (акмеоквалитология образования). - Казань: Центр инновационных технологий, 2013. - 296 с.

3. Ветрова Я.А. Динамика акмеологической позиции педагога в процессе повышения квалификации: дис. ... кандидата психологических наук. - Томск, 2014.- 193 C.

4. Григорьева С.Г. К проблеме инновационной деятельности в современных условиях // Среднее профессиональное образование. - 2010 - № 11 - С. 9-12.

5. Пряжникова Е.Ю., Пряжников Н.С. Психология труда и человеческого достоинства. - М.: Издательский центр «Академия», 2005. - 480 с.

6. Психология профессиональной деятельности: Лекции «в помощь преподавателю» / Под общ. ред. А.А. Деркача. - М.: Изд-Во РАГС, 2004. - 342 с.

7. Славнов С.В. Структурно-динамические характеристики образа успешного профессионала налоговой полиции // Психологический журнал. - 2003. - № 1, T. 24. - C. 82-90.

8. Трещев А.М. Субъектная позиция личности: учеб. пособие. - Калуга: КГПУ, 2001.- 145 с.

9. Троянская А.И. Профессиональная рефлексия личности в мире этнической культуры. Монография. - Ижевск: УдГУ, 2011. - 119 с.

10. Щербакова Т.Н., Мисиров Д.Н. Психологическая компетентность и успешность профессиональной подготовки менеджеров // Известия ЮФу. Педагогические науки. - 2011. - № 12. - С. 47-59.

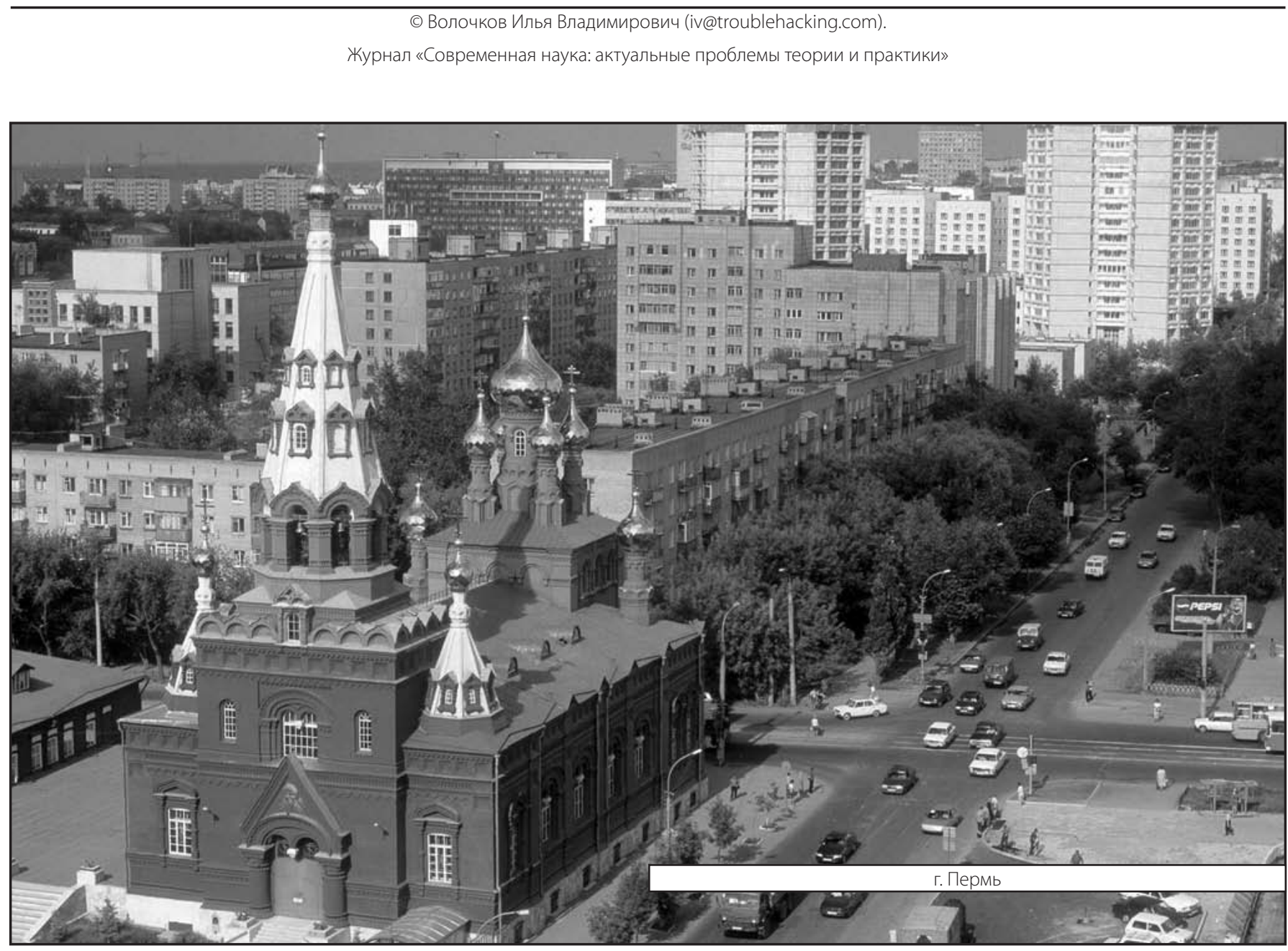

